\title{
Study Bacteriocin Production and Optimization Using New Isolates of Lactobacillus spp. Isolated from Some Dairy Products under Different Culture Conditions
}

\author{
Hoda Mahrous $^{1 *}$, Abeer Mohamed ${ }^{2}$, M. Abd El-Mongy ${ }^{2}$, A. I. El-Batal ${ }^{3}$, H. A. Hamza ${ }^{2}$ \\ ${ }^{1}$ Department of Industrial Biotechnology, Genetic Engineering and Biotechnology Research Institute, Menoufiya University, Shibin \\ El Kom, Egypt; ${ }^{2}$ Department of Microbial Biotechnology, Genetic Engineering and Biotechnology Research Institute, Menoufiya \\ University, Shibin El Kom, Egypt; ${ }^{3}$ National Center for Radiation Research and Technology, Cairo, Egypt. \\ Email: "hmahrous7@yahoo.com
}

Received October $8^{\text {th }}, 2012$; revised January $24^{\text {th }}, 2013$; accepted February $1^{\text {st }}, 2013$

\begin{abstract}
Lactobacilli belong to the group of lactic acid bacteria (LAB), that have several distinguished abilities such as production of lactic acid, enzymes such as $\beta$-Galactosidase and natural antimicrobial substances called bacteriocins. Bacteriocin is a biopreservative agent potential of suppressing growth of some contaminant bacteria in food industry but its commercial availability is limited and costly. The study aimed to select isolates of Lactobacillus spp. potential for producing bacteriocins to suppress the growth of Escherichia coli ATCC 25922 and Bacillus subtilis NCIB3610, and to optimize the process of bacteriocin production. Results obtained in this study showed that L. acidophilus isolate $\mathrm{CH} 1$ was selected as the best candidate for bacteriocin among the four isolates that tested. The largest amounts of the bacteriocins were synthesized only in MRS medium was supplemented with $\mathrm{K}_{2} \mathrm{HPO}_{4}(1.0 \%)$, Tween $80(1 \%)$, Beef extract $(1 \%)$, glucose, cyctein and peptone extract $(1 \%)$. The optimization of culture conditions for bacteriocin production areas showed that corn steep liquor medium was the best medium for all isolates against Bacillus subtilis while no effect was observed on Escherichia coli ATCC 25922 except when used MRS medium. The optimum conditions for bacteriocin production were $\mathrm{pH} 6.0$, temperature $34^{\circ} \mathrm{C}$ with $4 \%$ Phenyl acetamide showing the greatest growth inhibition areas.
\end{abstract}

Keywords: Lactobacillus acidophilus; Lactic Acid Bacteria; Bacteriocins Production

\section{Introduction}

Lactic acid bacteria (LAB) produce a number of antimicrobial substances such as organic acids, free fatty acids, ammonia, reuterin, diacetyl, hydrogen peroxide and bacteriocin, which have the capacity to inhibit the growth of food spoilage and pathogenic organisms [1]. Bacteriocins are proteinaceous and ribosomally synthesized antibacterial compounds produced by certain LAB during lactic acid fermentations that exhibit bactericidal activity against closely related species $[2,3]$. In recent years, a renewed interest in bacteriocin like activities has led to the discovery, isolation, and purification of bacteriocins from both gram-negative and gram-positive bacteria. They are now being considered for a variety of antimicrobial uses in foods and medicine [4]. Some bacteriocins produced by lactic acid bacteria, such as nisin, inhibit not only closely related species but are also effective against foodborne pathogens and many other gram-positive spoilage bacteria [5]. For this reason, bacteriocins have attracted

"Corresponding author. considerable interest for use as natural food preservatives in recent years, which have led to the discovery of ever increasing potential sources of these protein inhibitors.

LAB bacteriocins are divided into three main groups, based on their amino acid sequence, mode of action, heat tolerance, biological activity, presence of modified amino acids, and secretion mechanism. The classes I and II are further divided into subgroups, and the members of these classes are the most studied because they are so widespread among the LAB and due to their heat stability. The class III bacteriocins are heat-labile and therefore less interesting in the terms of food processing and protection. Quite recently a new classification has been proposed by Cotter et al. [6]. In this scheme the most dramatic change is the removal of class III bacteriocins to their own group of "bacteriolycins", hence making the group of bacteriocins smaller and more strictly defined.

Lactobacillus bacteriocins are found within each of the four major classes. Class I bacteriocins (antibiotics) were discovered in the lactobacillaceae by Mortvedt et al. [7]. These bacteriocins are small membrane-active peptids 
$(<5 \mathrm{kDa})$ containing an unusual amino acids, lanthionine. The class II bacteriocins are small heatstable, non-lanthionine containing and membrane-active peptides $(<10$ $\mathrm{kDa})$. The class III bacteriocins, have been found in Lactobacillus, include heat labile proteins of large molecular mass. The class IV bacteriocins are a group of complex proteins, associated with other lipid or carbohydrate moieties, which appear to be required for activity. They are relatively hydrophobic and heat stable [8].

Different bacteriocin exhibits different inhibition profile on food spoilage and pathogenic microorganisms. Therefore, they could be natural replacements for synthetic food preservatives [9]. In order to increase the productivity of bacteriocins, a better understanding of factors affecting their production is essential. Bacteriocin production has been reported to be affected by several factors including carbon and nitrogen sources; and fermentation conditions, such as $\mathrm{pH}$, temperature and agitation [9].

The optimization of bacteriocin production and enhancement of its activity are economically important to reduce the production cost. Thus, the aims of this study were to formulate industrial media for bacteriocin production by four lactic acid bacteria isolates and the optimization of culture conditions for maximizing bacteriocin production.

\section{Materials and Methods}

\subsection{Isolation and Identification of Lactic Acid Bacteria}

The lactic acid bacteria were isolated from raw milk and Ras cheese, by appropriate dilutions with $\mathrm{NaCl}$ physiological. Dilutions $\left(10^{-1}-10^{-6}\right)$ were prepared and plated on de Man Rogosa agar (MRS agar) medium (Hi Media Laboratory Pvt. Ltd. Mumbai, India) to isolate the $\mathrm{Lac}$ -

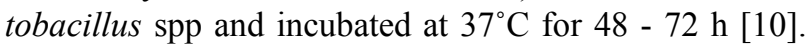
The strains were sub-cultured onto MRS agar slant incubated at $30^{\circ} \mathrm{C}$ for $24 \mathrm{~h}$ and preserved in $20 \%$ glycerol at $-80^{\circ} \mathrm{C}$. One of the isolates was selected for further studies. It exhibited strong inhibitory activity against indicator strains. It was identified on the basis of growth, cell morphology, gram staining and catalase activity. Further, identification was performed according to carbohydrate fermentation patterns and growth at $15^{\circ} \mathrm{C}$ and $45^{\circ} \mathrm{C}$ in the de Man Rogosa Sharpe (MRS) broth based on the characteristics of the lactobacilli as described in Bergey's Manual of Determinative Bacteriology [11-14] and fermentation of different carbon sources (API 50 CHL, bioMerieux SA, France). The ability of these isolated strains to produce acids from different carbohydrates was determined by API 50 CHL test kit (bioMerieux SA, France).

\subsection{Selection of Isolates Producing Bacteriocin}

\subsubsection{Treatment of Bacteria Prior to Production of Bacteriocin}

The isolates were tested for their production of Bacteriocin. E. coli ATCC 25922 and Bacillus subtilis NCIB3610 were used as indicator microorganism in all assays. Indicator microorganisms used are propagated for $48 \mathrm{~h}$ in the Nutrient agar media, and at the temperatures indicated $30^{\circ} \mathrm{C}$.

\subsubsection{Detection of Antibacterial Activity}

The antimicrobial activity of the isolates during the growth phase against Gram negative bacterium E. coli ATCC 25922 and Gram positive bacterium Bacillus subtilis NCIB3610 was evaluated by deferred methods: 1) welldiffusion assay [15] and 2) Tetrazolium/formazan-test method [16].

\subsection{The Maximization of Bacteriocins Production}

\subsubsection{Determination of Bacteriocin Production at Different Culture Conditions}

The effects of different temperatures and initial $\mathrm{pH}$ on the bacteriocin production were tested. MRS broth (10 $\mathrm{mL}$ ) was inoculated with each isolate and incubated at different temperatures such as $10^{\circ} \mathrm{C}, 20^{\circ} \mathrm{C}, 30^{\circ} \mathrm{C}, 40^{\circ} \mathrm{C}$ and $50^{\circ} \mathrm{C}$ to study the effect of different temperatures on the bacteriocin production. The effect of initial medium $\mathrm{pH}$ on bacteriocin production was determined by adjusting the MRS broth to different $\mathrm{pH}$ levels of 2, 4, 6, 8 and 10 , respectively. Each tube was inoculated with $2.0 \% \mathrm{v} / \mathrm{v}$ of an $18 \mathrm{~h}$-old culture of the four isolates and incubated at $30^{\circ} \mathrm{C}$ for $96 \mathrm{~h}$, without agitation.

\subsubsection{Influence of Medium Component on the Production of Bacteriocins}

The effect of medium ingredients on bacteriocin production was evaluated using composed media. The supplements studied were tryptone, yeast extract, beef extract, triammonium citrate sodium acetate, $\mathrm{MgSO}_{4}-7 \mathrm{H}_{2} \mathrm{O}$, $\mathrm{K}_{2} \mathrm{HPO}_{4}, \mathrm{NaCI}$, glucose and tween $80(1 \%, 2 \%$ and $3 \%)$ for each. Then, cells were removed by centrifugation at 6 $000 \mathrm{rpm}$ for $20 \mathrm{~min}$. the culture media was adjusted to $\mathrm{pH} 7.0$ using $1 \mathrm{M} \mathrm{NaOH}$ to exclude the antimicrobial effect of organic acids, followed by filtration of the supernatant through a $0.2 \mathrm{ml}$ pore-size cellulose acetate filter.

\subsubsection{Influence of Different Media on the Production of Bacteriocins}

The effect of different medium on bacteriocin production was evaluated using media at $30^{\circ} \mathrm{C}$ for 48 hours. 
- Selective medium (MRS media) as control.

- Medium (A) Corn steep liquor-Lactose medium [17].

- Medium (B) Corn steep liquor-Lactose medium [18].

- Medium (D) Corn steep liquor medium [19].

- Medium (E) Glycerol-molasses-liquid medium [17]. Broth media were used as seed culture $(10 \%$ of the total volume of the fermentation medium). The culture was adjusted to $\mathrm{pH}$ 7.0.

\subsection{Optimization of Bacteriocins Activity}

\subsubsection{Production of Crude Bacteriocin Samples}

Lactobacillus species were cultured in $1000 \mathrm{ml}$ MRS broth (pH 7.0) for $48 \mathrm{~h}$ at $30^{\circ} \mathrm{C}$. For extraction of bacteriocins, a cell-free solution was obtained by centrifuging (6000 rpm for $20 \mathrm{~min}$. at $4^{\circ} \mathrm{C}$ ) the culture and was adjusted to $\mathrm{pH} 7.0[20,21]$.

\subsubsection{Effect of Temperature on Crude Bacteriocins Activity}

In order to test the heat resistance, $10 \mathrm{ml}$ of bacteriocin preparation was heated for 30 minutes at $30^{\circ} \mathrm{C}, 60^{\circ} \mathrm{C}$, $90^{\circ} \mathrm{C}$ and $121^{\circ} \mathrm{C}$ respectively. Residual bacteriocin activity was detected against $E$. coli and Bacillus subtilus at each of these temperatures [22] by teterazoluim chloride method.

\subsubsection{Effect of $\mathrm{pH}$ on Crude Bacteriocins Activity}

According to the method described by Karaoglu et al. [8], sensitivity of the cell-free supernatant to different $\mathrm{pH}$ values was tested by adjusting the $\mathrm{pH}$ of the bacteriocins in the range of $\mathrm{pH} 2$ to 10 with sterile IN Noah and IN $\mathrm{HC} 1$. Residual activity of each of the samples was determined against the indicator organism by agar-well diffusion assay.

\subsubsection{Effect of Surfactants on Crude Bacteriocins Activity}

The effect of surfactants on the bacteriocins was tested by adding SDS, CTAB, EDTA and Tween $80(0.5 \% \mathrm{v} / \mathrm{v}$ final concentration), to crude bacteriocins. Untreated bacteriocin preparation (positive control). All samples were incubated at room temperature for 2 hours then tested for residual antimicrobial activity by teterazolium formazan test.

\subsubsection{Effect of Organic Solvents on Crude Bacteriocins Activity}

Crude bacteriocin preparations were mixed with organic solvents including acetone, butanol, chloroform, ethanol, methanol and propanol at a final concentration of $0.5 \%$. Untreated bacteriocins preparation were used as (positive control). All samples were incubated at room temperature for 2 hours and tested for residual antimicrobial ac- tivity by teterazolium formazan test.

\subsubsection{Effect of Metal Ions on Crude Bacteriocins Activity}

In a separate experiment the effect of metal salts on bacteriocin was examined by adding $\mathrm{AgNO}_{3}, \mathrm{CuSO}_{4}, \mathrm{FeSO}$, $\mathrm{MgSO}_{4}, \mathrm{MnCl}_{2}$, and $\mathrm{ZnSO}_{4}$ (Merck) to $10 \mathrm{ml}$ of crude bacteriocin preparation ( $0.5 \%$ final concentration). Untreated bacteriocin preparation (positive control). All samples were incubated at room temperature for 2 hours and tested for residual antimicrobial activity $[23,24]$ by teterazolium formazan test.

\subsubsection{Effect of Different Concentration of $\mathrm{NaCl}$ on Crude Bacteriocins Activity}

In a separate experiment the effect of different concentration of $\mathrm{NaCl}(2 \%, 4 \%, 6 \%, 8 \%, 10 \%)$ on bacteriocins were examined by adding to $10 \mathrm{ml}$ of crude bacteriocins preparation. Untreated bacteriocin preparation (positive control). All samples were incubated at room temperature for 2 hours and tested for residual antimicrobial activity [24] by agar-well diffusion assay.

\subsubsection{Effect of Different Concentration of Amino Acids on Crude Bacteriocins Activity}

In a separate experiment the effect of different concentration of 21 amino acids compound (essential amino acids) $(2 \%, 4 \%, 6 \%, 8 \%$ and $10 \%)$ on bacteriocins were examined by adding to $10 \mathrm{ml}$ of crude bacteriocins preparation. Untreated bacteriocin preparation (positive control). All samples were incubated at room temperature for 2 hours and tested for residual antimicrobial activity by agar-well diffusion assay.

\subsubsection{Effect of Different Concentration of Vitamins on Crude Bacteriocins Activity}

In a separate experiment the effect of different concentration of vitamins $(50 \%)$ such as (B12 and B complex) on bacteriocins were examined by adding (1) to $10 \mathrm{ml}$ of crude bacteriocins preparation. Untreated bacteriocin preparation (positive control). All samples were incubated at room temperature for 2 hours and tested for residual antimicrobial activity by agar-well diffusion assay.

\subsection{Statistical Analysis}

Data are presented as the mean \pm standard deviation, and $\mathrm{n}$ represents the number of the isolates and the control.

\section{Results and Discussion}

\subsection{Isolation and Identification of Bacteriocinogenic Strains}

Sixteen isolates of LAB were isolated from the samples. 
Isolated from Some Dairy Products under Different Culture Conditions

After series of purification on MRS agar, four isolates were found to be Gram-positive, catalase negative, nonmotile bacilli. In addition, all strains were tested for growth at $10^{\circ} \mathrm{C}$ for 10 days, $45^{\circ} \mathrm{C}$ for $48 \mathrm{~h}$, and $\mathrm{CO}_{2}$ production from glucose [25]. Table 1 presents the results of the final identifications for each type of isolates with API gallery as stated below: L. acidophilus M2, L. acidophilus $\mathrm{CH} 1$, L. fermentum $\mathrm{M} 1$ and L. pentosus $\mathrm{CH} 2$.

\subsection{Bacteriocin Production}

The antibacterial activity of bacteriocins against food borne pathogenic, as well as spoilage bacteria has raised considerable interest for their application in food preservation [26]. Application of bacteriocins may help reduce the use of chemical preservatives and/or the intensity of heat and other physical treatments, satisfying the demands of consumers for foods that are fresh tasting, ready to eat, and lightly preserved. In the present study the average diameter of the inhibition zones measured ranged from $2-20 \mathrm{~mm}$ in size (Table 2). Among the isolates, L. fermentum $\mathrm{M} 1$ and L. acidophilus $\mathrm{CH} 1$ were bacteriocin effectively inhibited the Bacillus subtilis NCIB3610 with maximum inhibitory activity, compared to the other tested bacteria while, the impact of these strains were less against E. coli ATCC 25922. In addition, L. acidophilus $\mathrm{M} 2$ exhibited stronger inhibition activity on Bacillus subtilis NCIB3610 than E. coli ATCC 25922 but its effect was less than the effect of L. acidophilus $\mathrm{CH} 1$ that exemplifies a difference within the same species. The present $L$. pentosus $\mathrm{CH} 2$ isolate showed inhibitory activity against Bacillus subtilis NCIB3610 on the other hand it was less inhibitory activity against $E$. coli ATCC 25922. Such observations [27,28] made earlier are in tune with the results of the present study which confirmed that the bacteriocins of Gram-positive bacteria generally exhibit antagonistic activity against Gram-positive bacteria and the activity against Gram negative bac- teria is an unusual phenomenon and has been reported for the bacteriocins produced by Lactobacillus plantarum [29], the isolates were screened for antimicrobial spectrum against Gram-positive and Gram-negative bacteria using the AWD method.

\subsection{Effect of Culture Conditions and Medium Composition on Bacteriocin Production}

The culture conditions and composition of the growth medium are very important for the production of individual bacteriocins [5]. Several media have been evaluated by numerous authors to improve bacteriocin synthesis [30] because these peptides are not always produced in standard or enriched culture media. Lactic acid bacteria are fastidious microorganisms that require rich media containing milk, whey ultrafiltrate, or complex synthetic media such as MRS [10], M17 [31] or LAPTg [32] for growth. Therefore, the isolation of a peptide(s) in richmedium supernatant is an additional problem, making the purification of the bacteriocin a relatively complicated protocol. The present study was primarily aimed to determine cultural conditions for obtaining better and stable bacteriocins production. L. acidophilus $\mathrm{CH} 1$ was able to produce bacteriocins, which had a wide inhibitory spectrum towards both Gram-negative and Gram-positive food spoilage and pathogenic bacteria. Results show that bacteriocin was produced when nutrients were available for metabolic activity. Tables $\mathbf{3}$ and $\mathbf{4}$ showed that maximum activity was noted at $\mathrm{pH} 6.0$, temperature $30^{\circ} \mathrm{C}$. Bacteriocin production is frequently regulated by $\mathrm{pH}$ and growth temperature, as has been shown in several studies involving the pediocin AcH [33]. From the results proved that it could be used in acidic foods like pickle or yoghurt. It might be secondary metabolites.

The composition of medium influencing the production of bacteriocin by Lactobacillus isolates. Table 5 showed that MRS seemed to be more suitable medium

Table 1. Pre-identification of some isolates.

\begin{tabular}{ccccccc}
\hline \multirow{2}{*}{ Strain } & \multicolumn{7}{c}{ Preliminary tests } & \multirow{2}{*}{ API Identification } \\
\cline { 2 - 6 } & Gram staining & Catalase test & Growth at $10^{\circ} \mathbf{C}$ & Growth at $45^{\circ} \mathbf{C}$ & $\mathbf{C O}_{2}$ Production & L. acidophilus \\
M2 & + & - & - & + & - & L. acidophilus \\
CH1 & + & - & - & + & + & L.pentousus \\
CH2 & + & - & - & + & - & L. fermentum \\
M1 & + & - & + & + &
\end{tabular}

Table 2. Bacteriocin production by four isolates Detected by well-diffusion assay.

\begin{tabular}{ccc}
\hline Strains & Diameter of the inhibition-zone $(\mathbf{m m})$ for B. subtilis & Diameter of the inhibition-zone (mm) for $\boldsymbol{E}$. coli \\
\hline L. fermentum M1 & $20 \pm 0.01$ & $3 \pm 0.02$ \\
L. acidophilus M2 & $18 \pm 0.02$ & $16 \pm 0.03$ \\
L. acidophilus CH1 & $20 \pm 0.01$ & $18 \pm 0.01$ \\
L. pentousus CH2 & $15 \pm 0.01$ & $2 \pm 0.02$ \\
\hline
\end{tabular}

Data are presented as mean $\pm \mathrm{SD}$. 
Table 3. Effect of different temperature on production.

\begin{tabular}{ccccccccc}
\hline Temp. & \multicolumn{3}{c}{$\begin{array}{c}\text { Diameter of the inhibition-zone (mm) } \\
\text { for E. coli ATCC 25922 }\end{array}$} & \multicolumn{3}{c}{$\begin{array}{c}\text { Diameter of the inhibition-zone (mm) } \\
\text { for Bacillus subtilis NCIB3610 }\end{array}$} \\
\cline { 2 - 11 } Strains & $\begin{array}{c}\text { L. fermentum } \\
\text { M1 }\end{array}$ & $\begin{array}{c}\text { L. acidophilus } \\
\text { M2 }\end{array}$ & $\begin{array}{c}\text { L. acidophilus } \\
\text { CH1 }\end{array}$ & $\begin{array}{c}\text { L. pentosus } \\
\text { CH2 }\end{array}$ & $\begin{array}{c}\text { L. fermentum } \\
\text { M1 }\end{array}$ & $\begin{array}{c}\text { L. acidophilus } \\
\text { M2 }\end{array}$ & $\begin{array}{c}\text { L. acidophilus } \\
\text { CH1 }\end{array}$ & $\begin{array}{c}\text { L. pentosus } \\
\text { CH2 }\end{array}$ \\
\hline Control & $20 \pm 0.01$ & $3 \pm 0.01$ & $9 \pm 0.01$ & $5 \pm 0.01$ & $3 \pm 0.01$ & $4 \pm 0.01$ & $16 \pm 0.01$ & $\mathbf{2} \pm 0.01$ \\
\hline $\mathbf{1 0}$ & $\mathbf{0 . 0}$ & $\mathbf{0 . 0}$ & $\mathbf{0 . 0}$ & $\mathbf{0 . 0}$ & $\mathbf{0 . 0}$ & $\mathbf{0 . 0}$ & $\mathbf{0 . 0}$ & $\mathbf{0 . 0}$ \\
$\mathbf{2 0}$ & $\mathbf{3} \pm 0.01$ & $\mathbf{4} \pm 0.01$ & $\mathbf{6} \pm 0.01$ & $\mathbf{4} \pm 0.01$ & $\mathbf{5} \pm 0.01$ & $\mathbf{4} \pm 0.01$ & $\mathbf{1 4} \pm 0.01$ & $\mathbf{6} \pm 0.01$ \\
$\mathbf{3 0}$ & $\mathbf{4} \pm 0.01$ & $\mathbf{3} \pm 0.01$ & $\mathbf{1 6} \pm 0.01$ & $\mathbf{7} \pm 0.01$ & $\mathbf{4} \pm 0.01$ & $\mathbf{5} \pm 0.01$ & $\mathbf{2 1} \pm 0.01$ & $\mathbf{7} \pm 0.01$ \\
$\mathbf{4 0}$ & $\mathbf{3} \pm 0.01$ & $\mathbf{5} \pm 0.01$ & $\mathbf{9} \pm 0.01$ & $\mathbf{3} \pm 0.01$ & $\mathbf{3} \pm 0.01$ & $\mathbf{2} \pm 0.01$ & $\mathbf{1 5} \pm 0.01$ & $\mathbf{6} \pm 0.01$ \\
$\mathbf{5 0}$ & $\mathbf{0 . 0}$ & $\mathbf{0 . 0}$ & $\mathbf{0 . 0}$ & $\mathbf{0 . 0}$ & $\mathbf{0 . 0}$ & $\mathbf{0 . 0}$ & $\mathbf{0 . 0}$ & $\mathbf{0 . 0}$ \\
\hline
\end{tabular}

Data are presented as mean $\pm \mathrm{SD}$.

Table 4. Effect of different $\mathrm{pH}$ on production.

\begin{tabular}{|c|c|c|c|c|c|c|c|c|}
\hline \multirow{2}{*}{ Strains } & \multicolumn{4}{|c|}{$\begin{array}{l}\text { Diameter of the inhibition-zone (mm) } \\
\text { for E. coli ATCC } 25922\end{array}$} & \multicolumn{4}{|c|}{$\begin{array}{l}\text { Diameter of the inhibition-zone (mm) } \\
\text { for mBacillus subtilis NCIB3610 }\end{array}$} \\
\hline & $\begin{array}{l}\text { L. fermentum } \\
\text { M1 }\end{array}$ & $\begin{array}{l}\text { L. acidophilus } \\
\text { M2 }\end{array}$ & $\begin{array}{c}\text { L. acidophilus } \\
\text { CH1 }\end{array}$ & $\begin{array}{l}\text { L. pentosus } \\
\text { CH2 }\end{array}$ & $\begin{array}{l}\text { L. fermentum } \\
\text { M1 }\end{array}$ & $\begin{array}{l}\text { L. acidophilus } \\
\text { M2 }\end{array}$ & $\begin{array}{l}\text { L. acidophilus } \\
\text { CH1 }\end{array}$ & $\begin{array}{l}\text { L. pentosus } \\
\text { CH2 }\end{array}$ \\
\hline Control & $2 \pm 0.01$ & $3 \pm 0.01$ & $9 \pm 0.01$ & $5 \pm 0.01$ & $3 \pm 0.01$ & $4 \pm 0.01$ & $16 \pm 0.01$ & $\mathbf{2} \pm 0.01$ \\
\hline 2 & $\mathbf{1} \pm \mathbf{0 . 0 1}$ & 0.0 & $\mathbf{2} \pm 0.01$ & 0.0 & 0.0 & $\mathbf{1} \pm 0.01$ & $3 \pm 0.01$ & 0.0 \\
\hline 4 & $\mathbf{2} \pm 0.01$ & $\mathbf{1} \pm 0.01$ & $\mathbf{3} \pm 0.01$ & $\mathbf{1} \pm 0.01$ & 0.0 & $\mathbf{1} \pm 0.01$ & $\mathbf{4} \pm 0.01$ & 0.0 \\
\hline 6 & $2 \pm 0.01$ & $3 \pm 0.01$ & $\mathbf{1 0} \pm 0.01$ & $7 \pm 0.01$ & $4 \pm 0.01$ & $\mathbf{4} \pm 0.01$ & $\mathbf{2 0} \pm 0.01$ & $7 \pm 0.01$ \\
\hline 8 & $\mathbf{1} \pm 0.01$ & $\mathbf{2} \pm 0.01$ & $\mathbf{5} \pm 0.01$ & $\mathbf{2} \pm 0.01$ & $\mathbf{2} \pm 0.01$ & $\mathbf{2} \pm 0.01$ & $\mathbf{1 0} \pm 0.01$ & $\mathbf{1 0} \pm 0.01$ \\
\hline 10 & 0.0 & 0.0 & 0.0 & 0.0 & 0.0 & 0.0 & 0.0 & 0.0 \\
\hline
\end{tabular}

Data are presented as mean $\pm \mathrm{SD}$.

for the bacteriocin production. Similar results were observed by [34,35]. Results in Table 5 also indicate that larger amounts of the bacteriocins were synthesized only in MRS medium supplemented with $\mathrm{K}_{2} \mathrm{HPO}_{4}(1.0 \%)$, Tween $80(1 \%)$, Beef extract (1\%), glucose, cyctein and peptone extract $(1 \%)$, while addition of tri-ammonium citrate, sodium acetate and magnesium sulphate, had no effect on bacteriocin production. Thus variation in the concentration of constituents/ supplementation of cultivation media might have an influence on the amount of bacteriocin produced by microorganisms. Similar observations have been made previously. Daba et al. [21] obtained similar results in the production of mensenterocin 5. Biswas et al. [33] compared the production of pediocin $\mathrm{ACH}$ by Pediococcus acidilactici $\mathrm{H}$ cultivated in TGE broth, MRS broth and several modifications of it. Modification of nutrients of cultivation media should be considered for maximal production of bacteriocin that has potential use as a food biopreservative [33]. Similar results were recorded for nisin [36] and pediocin AcH [33]. The reason for increased bacteriocin production is not clear and yet to be ascertained. Most of the bacteriocin producing organisms requires stabilizers or a unique me- dium composition for bacteriocin synthesis. It is probable that the yeast extract may in part serve to inactivate an inhibitor of bacteriocin synthesis [37]. Being a surfactant Tween 80 , might enable the discharging of the bacteriocin from the cell surface of the producer strain. This finding was supported by the increased bacteriocin production in the medium supplemented with different concentrations of yeast extract plus Tween-80.

An earlier study by the senior author [28] revealed that in L. plantaram MTCC1746, maximum bacteriocin production could be achieved by providing $1.5 \%$ yeast extract and $1.5 \%$ Tween- 80 . The addition of $\mathrm{MgSO}_{4}$ could make a slight impact on the production of bacteriocin. Activity of $1000 \mathrm{AU} / \mathrm{mL}$ was observed by the addition of this substrate at a lower concentration of $0.02 \%$ to $0.04 \%$. The higher concentrations $1 \%, 2 \%$ and $3 \%$, however, bring about reduction in bacteriocin production.

\subsection{Influence of Different Media on the Production of Bacteriocins}

Several complex culture media of high cost have been used for bactenocins production. In the current study, we have used an effluent from the food industry (Corn sleep 
Table 5. Effect of adding some nutrient components in MRS media on bacteriocins production by Lactobacillus spp. isolates.

\begin{tabular}{|c|c|c|c|c|c|c|c|c|c|}
\hline \multirow{3}{*}{ Medium Constituents } & \multirow{3}{*}{$\%$} & \multicolumn{8}{|c|}{ Diameter of the inhibition-zone (mm) } \\
\hline & & \multicolumn{4}{|c|}{ E. coli ATCC 25922} & \multicolumn{4}{|c|}{ Bacillus subtilis NCIB3610 } \\
\hline & & M1 & M2 & CH1 & CH2 & M1 & M2 & CH1 & CH2 \\
\hline \multirow[t]{2}{*}{ MRS (control) } & & 2 & 3 & 9 & 5 & 3 & 4 & 16 & 2 \\
\hline & 1 & 0.00 & 3 & 9 & 0.00 & 0.00 & 0.00 & 10 & 0.00 \\
\hline \multirow[t]{3}{*}{ MRS + Yeast extract } & 2 & 0.00 & 0.00 & 0.00 & 0.00 & 0.00 & 0.00 & 9 & 0.00 \\
\hline & 3 & 0.00 & 0.00 & 0.00 & 0.00 & 0.00 & 0.00 & 0.00 & 0.00 \\
\hline & 1 & 10 & 0.00 & 13 & 0.00 & 0.00 & 0.00 & 25 & 0.00 \\
\hline \multirow[t]{3}{*}{ MRS + Beef extract } & 2 & 15 & 0.00 & 17 & 10 & 0.00 & 0.00 & 0.00 & 0.00 \\
\hline & 3 & 0.00 & 0.00 & 0.00 & 0.00 & 0.00 & 0.00 & 0.00 & 0.00 \\
\hline & 1 & 0.00 & 0.00 & 0.00 & 0.00 & 5 & 7 & 24 & 0.00 \\
\hline \multirow[t]{3}{*}{ MRS + Peptone extract } & 2 & 0.00 & 0.00 & 0.00 & 0.00 & 0.00 & 0.00 & 0.00 & 0.00 \\
\hline & 3 & 0.00 & 0.00 & 0.00 & 0.00 & 0.00 & 0.00 & 0.00 & 0.00 \\
\hline & 1 & 0.00 & 0.00 & 0.00 & 0.00 & 0.00 & 0.00 & 13 & 0.00 \\
\hline \multirow[t]{3}{*}{ MRS + Glucose } & 2 & 0.00 & 0.00 & 15 & 0.00 & 0.00 & 0.00 & 11 & 0.00 \\
\hline & 3 & 9 & 19 & 11 & 9 & 0.00 & 0.00 & 0.0 & 0.00 \\
\hline & 1 & 0.00 & 0.00 & 12 & 0.00 & 0.00 & 0.00 & 23 & 0.00 \\
\hline \multirow[t]{3}{*}{ MRS + Tween80 } & 2 & 0.00 & 0.00 & 0.00 & 0.00 & 0.00 & 0.00 & 15 & 0.00 \\
\hline & 3 & 0.00 & 0.00 & 5 & 9 & 8 & 12 & 20 & 0.00 \\
\hline & 1 & 1 & 2 & 3 & 5 & 9 & 0.00 & 19 & 0.00 \\
\hline \multirow[t]{3}{*}{ MRS + Sodium acetate } & 2 & 2 & 2 & 4 & 2 & 0.00 & 0.00 & 0.00 & 0.00 \\
\hline & 3 & 0.00 & 0.00 & 0.00 & 0.00 & 0.00 & 0.00 & 0.00 & 0.00 \\
\hline & 1 & 4 & 0.00 & 0.00 & 0.00 & 0.00 & 5 & 10 & 0.00 \\
\hline \multirow[t]{3}{*}{ MRS + Tri-ammonium citrate } & 2 & 0.00 & 0.00 & 0.00 & 0.00 & 0.00 & 0.00 & 0.00 & 0.00 \\
\hline & 3 & 0.00 & 0.00 & 0.00 & 0.00 & 0.00 & 0.00 & 0.00 & 0.00 \\
\hline & 1 & 0.00 & 11 & 12 & 5 & 6 & 6 & 16 & 0.00 \\
\hline \multirow[t]{3}{*}{$\mathrm{MRS}+\mathrm{MgSo}_{4} \cdot 7 \mathrm{H}_{2} \mathrm{O}$} & 2 & 0.00 & 5 & 0.0 & 0.00 & 7 & 0.0 & 0.0 & 0.00 \\
\hline & 3 & 0.00 & 0.0 & 0.0 & 0.0 & 0.0 & 0.0 & 0.0 & 0.00 \\
\hline & 1 & 12 & 10 & 20 & 0.00 & 0.00 & 0.00 & 15 & 0.00 \\
\hline \multirow[t]{3}{*}{ MRS + Cyctein } & 2 & 0.00 & 0.00 & 15 & 0.00 & 0.00 & 0.00 & 11 & 0.00 \\
\hline & 3 & 0.00 & 0.00 & 25 & 15 & 0.00 & 0.00 & 10 & 0.00 \\
\hline & 1 & 0.00 & 0.00 & 0.00 & 10 & 9 & 20 & 27 & 0.00 \\
\hline \multirow[t]{2}{*}{$\mathrm{MRS}+\mathrm{K}_{2} \mathrm{HPO}_{4}$} & 2 & 0.00 & 0.00 & 0.00 & 9 & 0.00 & 9 & 13 & 0.00 \\
\hline & 3 & 0.00 & 0.00 & 0.00 & 0.00 & 0.00 & 0.00 & 0.00 & 0.00 \\
\hline
\end{tabular}

liquar (CSL), CSL with glucose and glysrol culture media for bacteriocins production of at low costs. These media were used for bactenocin production by four lactic acid bacteria isolates (Lactobacillus fermentum M1, Lactobacillus acidophilus M2, Lactobacillus acidophilus $\mathrm{CH} 1$ and Lactobacillus pentosus $\mathrm{CH} 2$ ). Production of bacteriocins at $30^{\circ} \mathrm{C}$ and at a $\mathrm{pH} 6.5$ were carried out in different media MRS, Medium (A) Corn steep liquorLactose medium, Medium (B) Corn steep liquor-Lactose medium, Medium (C) Corn steep liquor medium, Medium (D) Glycerol-molasses-liquid medium for bacteriocins (Table 6). A maximum growth rate were shown in MRS and CSL for all isolates and a maximum bacteriocrn activity (inhibition zone $\mathrm{mm}$ of Bacillus subtilis
NCIB3610) was appeared by-isolate Lactobacillus acidophilus $\mathrm{CH} 1$ in medium $\mathrm{C}$, but the maximum bacteriocm activity by isolate $\mathrm{CH} 1$. On the other hand isolates $\mathrm{CHl}$ and $\mathrm{M} 1$ were given the maximum bacteriocm(s) activity in meadium $\mathrm{C}$. The lowest amounts of bacteriocins activity were produced in date by M1 isolate. Although this fact suggests the possible effect of substrate inhibition, it could also be related to the control that the supplied sugar substrate exerts on the bacteriocm biosynthesis. Biswas et al. [33] reported that MRS medium is a better medium for cell growth and bacteriocins production than other media. Generally, maximum production corresponds to against pathogenic microbe such as Bacillus subtilis NCIB3610 and E. coli ATCC 25922. 
Table 6. Effect of different media on production of bacteriocins.

\begin{tabular}{|c|c|c|c|c|c|c|c|c|}
\hline \multirow{2}{*}{$\begin{array}{l}\text { Strains } \\
\text { Media }\end{array}$} & \multicolumn{4}{|c|}{$\begin{array}{l}\text { Diameter of the inhibition-zone (mm) } \\
\text { for Bacillus subtilis NCIB3610 }\end{array}$} & \multicolumn{4}{|c|}{$\begin{array}{l}\text { Diameter of the inhibition-zone (mm) } \\
\text { for } E \text {. coli ATCC } 25922\end{array}$} \\
\hline & $\begin{array}{l}\text { L. fermentum } \\
\text { M1 }\end{array}$ & $\begin{array}{l}\text { L. acidophilus } \\
\text { M2 }\end{array}$ & $\begin{array}{l}\text { L. acidophilus } \\
\text { CH1 }\end{array}$ & $\begin{array}{l}\text { L. pentosus } \\
\text { CH2 }\end{array}$ & $\begin{array}{l}\text { L. fermentum } \\
\text { M1 }\end{array}$ & $\begin{array}{l}\text { L. acidophilum } \\
\text { M2 }\end{array}$ & $\begin{array}{l}\text { L. acidophilus } \\
\text { CH1 }\end{array}$ & $\begin{array}{l}\text { L. pentosus } \\
\text { CH2 }\end{array}$ \\
\hline MRS control & 2 & 3 & 9 & 5 & 3 & 4 & 16 & 2 \\
\hline $\mathbf{A}$ & 8 & 0.0 & 10 & 0.0 & 0.0 & 0.0 & 0.0 & 0.0 \\
\hline B & 8 & 5 & 20 & 12 & 0.0 & 0.0 & 0.0 & 0.0 \\
\hline C & 5 & 25 & 32 & 20 & 0.0 & 0.0 & 0.0 & 0.0 \\
\hline D & 10 & 0.0 & 16 & 0.0 & 0.0 & 0.0 & 0.0 & 0.0 \\
\hline
\end{tabular}

Medium (A) Corn steep liquor-Lactose medium. Medium (B) Corn steep liquor-Lactose medium with some modifications. Medium (C) Corn steep liquor medium. Medium (D) Glycerol-molasses-liquid medium.

Therefore increased cell concentrations in a high celldensity reactor is expected to increase bactenocm production. In general bactencin production by lactic acid bacteria occurs during the active growth phase [29,38]. Conditions favouring bacterial growth and high cell densities are frequently beneficial to bactenocin production as well [38]. However, a high cell yield does not necessarily result in a high bactenocin activity since the latter may be limited by a low specific bacteriocin production, i.e. a low bacteriocin production per gram of cells [28]. Hence, there exists a rather complex relationship between environmental conditions and bactenocin activity levels and no generalisation about the optimum conditions for bactenocin production can readily be made. The kinetics of both cell growth and bactenocin production in function of the environmental situation have to be studied to obtain a better understanding of the production mechanism.

\subsection{Optimization of Bacteriocin Activity}

\subsubsection{Effect of Different Temperatures on the Crud Bacteriocin}

The effect of different temperatures on crud bacteriocin have been clarified in the Tables 7-10. These tables clearly highlights of effect of different temperature $30^{\circ} \mathrm{C}$, $60^{\circ} \mathrm{C}$ and $90^{\circ} \mathrm{C} / 30 \mathrm{~min}$ on crud bacteriocin from four LAB: L. fermentum M1, L. acidophilus M2, L. acidophilus $\mathrm{CH} 1$ and $L$. pentosus $\mathrm{CH} 2$ according to the teterazolium chloride methods. As can be seen, LAB were isolated from local raw milk and Ras cheese using MRS agar. According to Table 7, the isolated Lactobacillus fermentum M1 was showed antimicrobial activity against E.coli ATCC 25922 which showed the largest of growth inhibitor\% around $76.08 \%$ in temp. $60^{\circ} \mathrm{C} / 30 \mathrm{~min}$ bacteriocin but the smallest of the antimicrobial activity was $39.34 \%$ in temp. $90^{\circ} \mathrm{C} / 30 \mathrm{~min}$ wherever Lactobacillus fermentum was showed antimicrobial activity against $\mathrm{Ba}$ cillus subtilis NCIB3610 was $35.79 \%$ in temp. $60^{\circ} \mathrm{C} / 30 \mathrm{~min}$ but the smallest of the antimicrobial activity was $30 \%$ in temp. $30^{\circ} \mathrm{C} / 30 \mathrm{~min}$. Table 8 , in addition, the strains $L$. acidophilus M2 which showed the largest growth inhibition $\%$ was $80.32 \%$ in temp. $60^{\circ} \mathrm{C} / 30 \mathrm{~min}$ against Bacillus subtilis NCIB3610 but the smallest was $65.81 \%$ in temp. $90^{\circ} \mathrm{C} / 30 \mathrm{~min}$ wherever, the same strain was the largest growth inhibitor $\% 87.34 \%$ in temp. $60^{\circ} \mathrm{C} / 30 \mathrm{~min}$ but the smallest was $11.12 \%$ in temp. $30^{\circ} \mathrm{C} / 30 \mathrm{~min}$ against to $E$. coli.

According to Table 9 The isolated Lactobacillus acidophilus $\mathrm{CH} 1$ was showed antimicrobial activity against E.coli ATCC 25922 which showed the largest of growth inhibitor $\%$ around $59.56 \%$ in temp. $60^{\circ} \mathrm{C} / 30 \mathrm{~min}$ but that showed the smallest $18.08 \%$ in temp. $90^{\circ} \mathrm{C} / 30 \mathrm{~min}$. Bacteriocin wherever Lactobacillus acidophilus $\mathrm{CH} 1$ was showed antimicrobial activity against Bacillus subtilis NCIB3610 was $87.08 \%$ in temp. $30^{\circ} \mathrm{C} / 30 \mathrm{~min}$ but the smallest of the antimicrobial activity was $18.08 \%$ in temp. $90^{\circ} \mathrm{C} / 30 \mathrm{~min}$. Table 10, in addition, the strains L. pentosus $\mathrm{CH} 2$ which showed the largest growth inhibition $\%$ was $85.98 \%$ in temp. $60^{\circ} \mathrm{C} / 30 \mathrm{~min}$ against Bacillus subtilis NCIB3610 but the smallest was $0.00 \%$ in temp. $60^{\circ} \mathrm{C} / 30 \mathrm{~min}$ wherever, the same strain was the largest growth inhibitor $\% 98.40 \%$ in temp. $90^{\circ} \mathrm{C} / 30 \mathrm{~min}$ against to E. coli.

An optimal temperature of $25^{\circ} \mathrm{C}$ for the production of bacteriocin by Leuconostoc carnosum LA54A was found by Geisen et al. [39]. Vignolo et al. [40] showed that production of lactocin 705 by Lactobacillus casei CRL 705 increased as the culture temperature was reduced: for every temperature tested $\left(15^{\circ} \mathrm{C} \pm 30^{\circ} \mathrm{C}\right)$, bacteriocin production levels were identical but biomass increased with the temperature. Moreover, the lower the temperature, the higher the volumic production, particularly for mesenterocin $52 \mathrm{~A}$. This indicated that bacteriocin production was stimulated by temperatures unfavorable for growth, particularly the low temperatures.

\subsubsection{Effect of Different Levels of $\mathrm{pH}$ on the Crud Bacteriocin}

The effects of different $\mathrm{pH}$ such as 2, 4, 6, 8 and 10 on crude of bacteriocins were studied. In MRS broth, $\mathrm{pH} 2$ 
Table 7. Effect of temperature on crude bacteriocins.

\begin{tabular}{ccccccc}
\hline & \multicolumn{9}{c}{ L. fermentum M1 } \\
\cline { 2 - 7 } & O.D & Growth \% & Growth inhibitor \% & O.D & Growth \% & Growth inhibitor \% \\
\cline { 2 - 7 } & 0.813 & 100 & 0.00 & 1.350 & 100 & 0.00 \\
\hline Control & 0.569 & 69.99 & $\mathbf{3 0 . 0 1}$ & 0.531 & 39.33 & 60.67 \\
$30^{\circ} \mathrm{C} / 30 \mathrm{~min}$ & 0.522 & 64.21 & $\mathbf{3 5 . 7 9}$ & 0.323 & 23.93 & $\mathbf{7 6 . 0 8}$ \\
$60^{\circ} \mathrm{C} / 30 \mathrm{~min}$ & 0.55 & 67.65 & 32.34 & 0.090 & 6.66 & $\mathbf{3 9 . 3 4}$ \\
$90^{\circ} \mathrm{C} / 30 \mathrm{~min}$ & & & & & & \multicolumn{1}{c}{ coli ATCC 25922 } \\
\hline
\end{tabular}

Table 8. Effect of temperature on crude bacteriocins.

\begin{tabular}{ccccccc}
\hline & \multicolumn{9}{c}{ L. acidophilus M2 } \\
\cline { 2 - 7 } & O.D & Growth \% & Growth inhibitor \% & O.D & Growth \% & Growth inhibitor \% \\
\cline { 2 - 7 } & 0.813 & 100 & 0.00 & 1.350 & 100 & 0.00 \\
\hline Control & 0.232 & 28.54 & 71.46 & 0.943 & 69.85 & 30.15 \\
$30^{\circ} \mathrm{C} / 30 \mathrm{~min}$ & 0.160 & 19.68 & $\mathbf{8 0 . 3 2}$ & 0.171 & 12.66 & $\mathbf{8 7 . 3 4}$ \\
$60^{\circ} \mathrm{C} / 30 \mathrm{~min}$ & 34.19 & $\mathbf{6 5 . 8 1}$ & 1.20 & 88.88 & $\mathbf{1 1 . 1 2}$ \\
$90^{\circ} \mathrm{C} / 30 \mathrm{~min}$ & 0.278 & & &
\end{tabular}

Table 9. Effect of temperature on crude bacteriocins.

\begin{tabular}{ccccccc}
\hline & \multicolumn{9}{c}{ L. acidophilus CH1 } \\
\cline { 2 - 7 } & O.D & Growth \% & Growth inhibitor \% & O.D & Growth \% & Growth inhibitor \% \\
\cline { 2 - 7 } & 0.813 & 100 & 0.00 & 1.350 & 100 & 0.00 \\
\hline Control & 0.105 & 12.92 & $\mathbf{8 7 . 0 8}$ & 1.007 & 74.59 & 25.41 \\
$30^{\circ} \mathrm{C} / 30 \mathrm{~min}$ & 0.411 & 50.55 & 49.45 & 0.546 & 40.44 & $\mathbf{5 9 . 5 6}$ \\
$60^{\circ} \mathrm{C} / 30 \mathrm{~min}$ & 0.666 & & $\mathbf{1 8 . 0 8}$ & 1.096 & 81.19 & $\mathbf{1 8 . 8 2}$ \\
$90^{\circ} \mathrm{C} / 30 \mathrm{~min}$ & & & & &
\end{tabular}

Table 10. Effect of temperature on crude bacteriocin.

\begin{tabular}{ccccccc}
\hline & \multicolumn{9}{c}{ L. pentosus CH2 } \\
\cline { 2 - 7 } & O.D & Growth \% & Growth inhibitor \% & O.D & Growth \% & Growth inhibitor \% \\
\cline { 2 - 7 } & 0.813 & 100 & 0.00 & 1.350 & 100 & 0.00 \\
\hline Control & 15 & 84.99 & 0.221 & 16.37 & 83.63 \\
$30^{\circ} \mathrm{C} / 30 \mathrm{~min}$ & 0.122 & 14.02 & $\mathbf{8 5 . 9 8}$ & 0.221 & 16.37 & 83.63 \\
$60^{\circ} \mathrm{C} / 30 \mathrm{~min}$ & 0.114 & 151.17 & -51.17 & 2.154 & 1.59 & $\mathbf{9 8 . 4 0}$ \\
$90^{\circ} \mathrm{C} / 30 \mathrm{~min}$ & 1.229 & & & & \\
\hline
\end{tabular}

increased the activity of bacteriocins isolated from $\mathrm{Lac}$ tobacillus acidophillus $\mathrm{CH} 1$ against to E. coli ATCC 25922 was $12 \mathrm{~mm}$ but the L. acidophillus M2, L. fermentum $\mathrm{M} 1$ and L. pentosus $\mathrm{CH} 2$ isolates were around (5, 9 , 10) $\mathrm{mm}$, wherever four isolates were decreased $\mathrm{pH}$ against to Bacillus subtilis NCIB3610 (Table 11). Among them, in $\mathrm{pH} 6$, the largest activity of bacteriocin from Lactobacillus acidophilus $\mathrm{CH} 1$, L. acidophillus $\mathrm{M} 2$, L. fermentum $\mathrm{M} 1$ and $L$. pentosus $\mathrm{CH} 2$ against $E$. coli ATCC 25922 was shown $11,11,28$ and $15 \mathrm{~mm}$, but isolates were decreased $\mathrm{pH}$ against to Bacillus subtilis NCIB3610. Among them, in $\mathrm{pH} \mathrm{8,} \mathrm{the} \mathrm{largest} \mathrm{activity} \mathrm{of} \mathrm{bacteriocin}$ from Lactobacillus acidophilus CH1, L. acidophillus M2,
L. fermentum $\mathrm{M} 1$ and $L$. pentosus $\mathrm{CH} 2$ against $E$. coli ATCC 25922 was shown 13, 10, 26 and $20 \mathrm{~mm}$, but isolates were decreased $\mathrm{pH}$ against to Bacillus subtilis NCIB3610. In pH 10, no activity for bacteriocin from Lactobacillus spp. against E. coli ATCC 25922 and $B a-$ cillus subtilis NCIB3610. So that, the activity of different bacteriocins were shown in pH6 against $E$. coli ATCC 25922 and the isolates were decreased against to Bacillus subtilis NCIB3610.

Thus, under uncontrolled $\mathrm{pH}$ conditions, a lower temperature coincided with a higher maximum bacteriocin production, a result also obtained by De Vugst et al. [41] with the bacteriocin from Lactobacillus amylovorus. 
Table 11. Effect of pH on crude bacteriocins.

\begin{tabular}{|c|c|c|c|c|c|c|c|c|}
\hline pH & & E. coli A & CC 25922 & & & Bacillus subt & lis NCIB3610 & \\
\hline Strains & $\begin{array}{c}\text { L. fermentum } \\
\text { M1 }\end{array}$ & $\begin{array}{c}\text { L. acidophilus } \\
\text { M2 }\end{array}$ & $\begin{array}{c}\text { L. acidophilus } \\
\text { CH1 }\end{array}$ & $\begin{array}{c}\text { L. pentosus } \\
\text { CH2 }\end{array}$ & $\begin{array}{c}\text { L. fermentum } \\
\text { M1 }\end{array}$ & $\begin{array}{c}\text { L. acidophilus } \\
\text { M2 }\end{array}$ & $\begin{array}{c}\text { L. acidophilus } \\
\text { CH1 }\end{array}$ & $\begin{array}{l}\text { L. pentosus } \\
\text { CH2 }\end{array}$ \\
\hline 2 & 10 & 9 & 12 & 5 & 6 & 8 & 9 & 5 \\
\hline 4 & 9 & 11 & 9 & 9 & 10 & 8 & 10 & 10 \\
\hline 6 & 11 & 11 & 28 & 20 & 5 & 5 & 33 & 5 \\
\hline 8 & 13 & 10 & 26 & 15 & 5 & 5 & 9 & 5 \\
\hline 10 & 0.0 & 0.0 & 0.0 & 0.0 & 0.0 & 0.0 & 0.0 & 0.0 \\
\hline
\end{tabular}

\subsubsection{Effect of Surfactant on Crude Bacteriocins}

Tables 12-15 clearly highlights of effect of different minerals such as SDS, ETDA, Tween80 and CTAB on crud bacteriocin from four LAB such as L. fermentum $\mathrm{M} 1$, L. acidophilus $\mathrm{M} 2$, L. acidophilus $\mathrm{CH} 1$ and L. pentosus $\mathrm{CH} 2$ according to the teterazolium chloride methods. As can be seen, LAB were isolated from local raw milk and Ras cheese using MRS agar. According to Table 12 The isolated Lactobacillus fermentum M1 was showed antimicrobial activity against $E$. coli ATCC 25922 which showed the largest of growth inhibitor\% around $73.56 \%$ in Tween 80 on bacteriocin but the smallest of the antimicrobial activity was $34.23 \%$ in CTAB wherever Lactobacillus fermentum was showed antimicrobial activity against Bacillus subtilis NCIB3610 was $47.48 \%$ in Tween 80 but the smallest of the antimicrobial activity was $12.42 \%$ in SDS. Table 13, in addition, the strains $L$. acidophilus M2 which showed the largest growth inhibition $\%$ was $78.59 \%$ in SDS against Bacillus subtilis NCIB3610 but the smallest was $11.44 \%$ in Tween 80 wherever, the same strain was the largest growth inhibitor $\% 74.52 \%$ in CTAB but the smallest was $39.4 \%$ in Tween 80 against to $E$. coli.

According to Table 14, the isolated Lactobacillus acidophilus $\mathrm{CH} 1$ was showed antimicrobial activity against E. coli ATCC 25922 which showed the largest of growth inhibitor $\%$ around $78.29 \%$ in Tween 80 but that showed the smallest $20 \%$ in CTAB. Bacteriocin wherever Lactobacillus acidophilus $\mathrm{CH} 1$ was showed antimicrobial activity against Bacillus subtilis NCIB3610 was $75.77 \%$ in Tween 80 but the smallest of the antimicrobial activity was $34.44 \%$ in SDS. Table 15, in addition, the strains L. pentosus $\mathrm{CH} 2$ which showed the largest growth inhibition\% was $49.57 \%$ in CTAB against Bacillus subtilis NCIB3610 but the smallest was $7.13 \%$ in Tween 80 wherever, the same strain was the largest growth inhibitor $\% 80.59 \%$ in CTAB against to $E$. coli but the smallest of the antimicrobial activity was $40.89 \%$ in ETDA. Similar observation was made earlier in L. acidophilus [42].

\subsubsection{Effect of Organic Solvents on Crude Bacteriocins Activity}

Tables 16-19 clearly highlights of effect of different sol- vent such as ethanol, Isopropanol, Isoamylchlorde and chrolform on crud bacteriocin from four LAB such as $L$. fermentum M1, L. acidophilus $\mathrm{M} 2$, L. acidophilus $\mathrm{CH} 1$ and L. pentosus $\mathrm{CH} 2$ according to the teterazolium chloride methods.

As can be seen, LAB were isolated from local raw milk and Ras cheese using MRS agar. According to Table 16, the isolated Lactobacillus fermentum M2 was showed antimicrobial activity against $E$. coli ATCC 25922 which showed the largest of growth inhibitor $\%$ around $60.67 \%$ in ethanol bacteriocin wherever Lactobacillus fermentum was showed antimicrobial activity against Bacillus subtilis NCIB3610 was $93.85 \%$ in Iso amyl chloride but the smallest of the antimicrobial activity was $30 \%$ in ethanol. Table 17, in addition, the strains $\mathrm{L}$. acidophilus M2 which showed the largest growth inhibition $\%$ was $88.98 \%$ in chroloform against Bacillus subtilis NCIB3610 but the smallest was $46.87 \%$ in ethanol wherever, the same strain was the largest growth inhibitor $\%$ $87 \%$ in isopropanol but the smallest was $11.12 \%$ in Iso amyl chloride against to $E$. coli.

According to Table 18, the isolated Lactobacillus acidophilus $\mathrm{CH} 1$ was showed antimicrobial activity against E. coli ATCC 25922 which showed the largest of growth inhibitor $\%$ around $85.19 \%$ in ethanol but that showed the smallest $38.45 \%$ in isoamylchlorde. Bacteriocin wherever Lactobacillus acidophilus $\mathrm{CH} 1$ was showed antimicrobial activity against Bacillus subtilis NCIB3610 was $87.69 \%$ in ethanol but the smallest of the antimicrobial activity was $14.69 \%$ in chloroform. Table 19, in addition, the strains L. pentosus $\mathrm{CH} 2$ which showed the largest growth inhibition \% was $33.21 \%$ in ethanol against $\mathrm{Ba}$ cillus subtilis NCIB3610 but the smallest was $0.00 \%$ in chloroform wherever, the same strain was the largest growth inhibitor $\% 70.52 \%$ in ethanol but the smallest was $40.74 \%$ in isopropanol against to E. coli.

\subsubsection{Effect of Some Minerals Salt on Crude Bacteriocins}

Tables 20-23 clearly highlights of effect of different minerals such as $\mathrm{AgNo}_{3}, \mathrm{CuSo}_{4}, \mathrm{FeSo}_{4}, \mathrm{MgSo}_{4}, \mathrm{MnCl}_{2}$ and $\mathrm{ZnSo}_{4}$ on crud bacteriocin from four LAB isolates according to the teterazolium chloride methods. Tables 
Study Bacteriocin Production and Optimization Using New Isolates of Lactobacillus spp.

Isolated from Some Dairy Products under Different Culture Conditions

Table 12. Effect of surfactant on crude bacteriocins from Lactobacillus fermentum M1.

\begin{tabular}{|c|c|c|c|c|c|c|}
\hline \multirow[t]{3}{*}{ Isolates } & \multicolumn{6}{|c|}{ Lactobacillus fermentum M1 } \\
\hline & \multicolumn{3}{|c|}{ Baccillus subtilis NCIB3610 } & \multicolumn{3}{|c|}{ E. coli ATCC 25922} \\
\hline & O.D & Growth \% & Growth inhibitor \% & O.D & Growth \% & Growth inhibitor \% \\
\hline Control & 0.813 & 100 & 0.00 & 1.350 & 100 & 0.00 \\
\hline SDS & 0.712 & 87.58 & 12.42 & 0.739 & 54.74 & 45.26 \\
\hline ETDA & 0.576 & 71.09 & 28.91 & 1.766 & 130.81 & -30.81 \\
\hline Tween 80 & 0.427 & 52.52 & 47.48 & 0.357 & 26.44 & 73.56 \\
\hline CTAB & 0.465 & 57.19 & 42.80 & 0.888 & 65.78 & 34.23 \\
\hline
\end{tabular}

Table 13. Effect of surfactant on crude bacteriocins from Lactobacillus acidophillus M2.

\begin{tabular}{|c|c|c|c|c|c|c|}
\hline \multirow{3}{*}{ Isolates } & \multicolumn{6}{|c|}{ L. acidophillus M2 } \\
\hline & \multicolumn{3}{|c|}{ Baccillus subtilis NCIB3610 } & \multicolumn{3}{|c|}{ E. coli ATCC 25922} \\
\hline & O.D & Growth \% & Growth inhibitor \% & O.D & Growth \% & Growth inhibitor $\%$ \\
\hline Control & 0.813 & 100 & 0.00 & 1.350 & 100 & 0.00 \\
\hline SDS & 0.174 & 21.40 & 78.59 & 0.549 & 40.67 & 59.34 \\
\hline ETDA & 0.272 & 33.46 & 66.54 & 1.463 & 108.37 & -8.37 \\
\hline Tween 80 & 0.720 & 88.56 & 11.44 & 0.818 & 60.59 & 39.4 \\
\hline CTAB & 0.583 & 71.71 & 28.29 & 0.344 & 25.48 & 74.52 \\
\hline
\end{tabular}

Table 14. Effect of surfactant on crude bacteriocins from Lactobacillus acidophillus CH1.

\begin{tabular}{|c|c|c|c|c|c|c|}
\hline \multirow{3}{*}{ Isolates } & \multicolumn{6}{|c|}{ L. acidophillus CH1 } \\
\hline & \multicolumn{3}{|c|}{ Baccillus subtilis NCIB3610 } & \multicolumn{3}{|c|}{ E. coli ATCC 25922} \\
\hline & O.D & Growth \% & Growth inhibitor \% & O.D & Growth \% & Growth inhibitor \% \\
\hline Control & 0.813 & 100 & 0.00 & 1.350 & 100 & 0.00 \\
\hline SDS & 0.533 & 65.56 & 34.44 & 0.359 & 26.59 & 73.41 \\
\hline ETDA & 0.494 & 60.76 & 39.24 & 1.670 & 123.70 & -23.70 \\
\hline CTAB & 0.292 & 35.92 & 64.08 & 1.080 & 80 & 20 \\
\hline
\end{tabular}

Table 15. Effect of surfactant on crude bacteriocins from Lactobacillus pentosus CH2.

\begin{tabular}{|c|c|c|c|c|c|c|}
\hline \multirow{3}{*}{ Isolates } & \multicolumn{6}{|c|}{ L. pentosus $\mathrm{CH} 2$} \\
\hline & \multicolumn{3}{|c|}{ Baccillus subtilis NCIB3610 } & \multicolumn{3}{|c|}{ E. coli ATCC 25922} \\
\hline & O.D & Growth \% & Growth inhibitor \% & O.D & Growth \% & Growth inhibitor \% \\
\hline Control & 0.813 & 100 & 0.00 & 1.350 & 100 & 0.00 \\
\hline SDS & 0.512 & 62.98 & 37.02 & 1.907 & 141.25 & -14.25 \\
\hline ETDA & 0.503 & 61.87 & 38.13 & 0.798 & 59.11 & 40.89 \\
\hline CTAB & 0.410 & 50.43 & 49.57 & 0.262 & 19.41 & 80.59 \\
\hline
\end{tabular}

Table 16. Effect of different solvent on crude bacteriocin.

\begin{tabular}{|c|c|c|c|c|c|c|}
\hline \multirow{3}{*}{ Different Solvents } & \multicolumn{6}{|c|}{ Lactobacillus fermentum M1 } \\
\hline & \multicolumn{3}{|c|}{ Bacillus subtilis NCIB3610 } & \multicolumn{3}{|c|}{ E. coli ATCC 25922} \\
\hline & O.D & Growth \% & Growth inhibitor \% & O.D & Growth \% & Growth inhibitor \% \\
\hline Control & 0.813 & 100 & 0.00 & 1.350 & 100 & 0.00 \\
\hline Ethanol & 0.569 & 69.99 & 30.01 & 0.531 & 39.33 & 60.67 \\
\hline Isopropanol & 0.522 & 64.21 & 35.79 & 1.323 & 98 & 2 \\
\hline Chroloform & 0.554 & 68.14 & 31.86 & 0.00 & 0.00 & 0.00 \\
\hline
\end{tabular}


Table 17. Effect of different solvent on crude bacteriocin.

\begin{tabular}{|c|c|c|c|c|c|c|}
\hline \multirow{3}{*}{ Different Solvents } & \multicolumn{6}{|c|}{ Lactobacillus acidophilus M2 } \\
\hline & \multicolumn{3}{|c|}{ Bacillus subtilis NCIB3610 } & \multicolumn{3}{|c|}{ E. coli ATCC 25922} \\
\hline & O.D & Growth \% & Growth inhibitor \% & O.D & Growth \% & Growth inhibitor \% \\
\hline Control & 0.813 & 100 & 0.00 & 1.350 & 100 & 0.00 \\
\hline Ethanol & 0.10 & 12.30 & 87.69 & 0.20 & 14.81 & 85.19 \\
\hline Isopropanol & 0.683 & 84.00 & 15.99 & 0.767 & 56.81 & 43.19 \\
\hline Chroloform & 0.692 & 85.12 & 14.89 & 0.739 & 54.74 & 45.26 \\
\hline
\end{tabular}

Table 18. Effect of different solvent on crude bacteriocin.

\begin{tabular}{ccccccc}
\hline & \multicolumn{9}{c}{ Lactobacillus acidophilus CH1 } \\
\cline { 2 - 7 } Different Solvents & \multicolumn{3}{c}{ Bacillus subtilis NCIB3610 } & E. coli ATCC 25922 \\
\cline { 2 - 7 } & O.D & Growth \% & Growth inhibitor \% & O.D & Growth \% & Growth inhibitor \% \\
\hline Control & 0.813 & 100 & 0.00 & 1.350 & 100 & 0.00 \\
Ethanol & 0.432 & 53.14 & $\mathbf{4 6 . 8 7}$ & 0.943 & 69.85 & 30.15 \\
Isopropanol & 0.10 & 12.30 & 87.69 & 0.171 & 12.66 & $\mathbf{8 7 . 3 4}$ \\
Iso amyl chlode & 0.278 & 34.19 & 65.81 & 1.20 & 88.88 & $\mathbf{1 1 . 1 2}$ \\
Chroloform & 0.090 & 11.07 & $\mathbf{8 8 . 9 3}$ & 2.00 & 148.15 & -48.15 \\
\hline
\end{tabular}

Table 19. Effect of different solvent on crude bacteriocin.

\begin{tabular}{ccccccc}
\hline & \multicolumn{7}{c}{ Lactobacills pentosus CH2 } \\
\cline { 2 - 7 } Different Solvents & \multicolumn{7}{c}{ Bacillus subtilis NCIB3610 } & E. coli ATCC 25922 \\
\cline { 2 - 7 } & O.D & Growth \% & Growth inhibitor \% & O.D & Growth \% & Growth inhibitor \% \\
\hline Control & 0.813 & 100 & 0.00 & 1.350 & 100 & 0.00 \\
Ethanol & 0.543 & 66.79 & 33.21 & 0.398 & 29.48 & 70.52 \\
Isopropanol & 0.765 & 94.09 & 5.91 & 0.800 & 59.26 & 40.74 \\
Iso amyl chlode & 0.625 & 76.88 & 23.12 & 0.699 & 51.78 & 48.23 \\
Chroloform & 0.00 & 0.00 & 0.00 & 0.421 & 30.52 & 69.48 \\
\hline
\end{tabular}

showed that LAB were isolated from local raw milk and Ras cheese using MRS agar. According to Table 20 The isolated Lactobacillus fermentum M1 was showed antimicrobial activity against E. coli ATCC 25922 which showed the largest of growth inhibitor\% around $86.89 \%$ in $\mathrm{MgSo}_{4}$ on bacteriocin but the smallest of the antimicrobial activity was $12.23 \%$ in $\mathrm{FeSo}_{4}$ wherever Lactobacillus fermentum was showed antimicrobial activity against Bacillus subtilis NCIB3610 was $87.20 \%$ in $\mathrm{FeSo}_{4}$ but the smallest of the antimicrobial activity was $39.36 \%$ in $\mathrm{CuSo}_{4}$. Table 21 showed that the L. acidophilus M2 isolate which showed the largest growth inhibition \% was 95.57\% in $\mathrm{FeSo}_{4}$ against Bacillus subtilis NCIB3610 but the smallest was $46.74 \%$ in $\mathrm{CuSo}_{4}$ wherever, the same strain was the largest growth inhibitor $\% 77.70 \%$ in $\mathrm{MgSo}_{4}$ but the smallest was $40.37 \%$ in $\mathrm{FeSo}_{4}$ against to $E$. coli.

According to Table 22, the Lactobacillus acidophilus $\mathrm{CH} 1$ isolate was showed antimicrobial activity against E.coli ATCC 25922 which showed the largest of growth inhibitor\% around $97.92 \%$ in $\mathrm{FeSo}_{4}$ but that showed the smallest $66.89 \%$ in $\mathrm{MgSo}_{4}$. Bacteriocin wherever Lactobacillus acidophilus $\mathrm{CH} 1$ was showed antimicrobial activity against Bacillus subtilis NCIB3610 was $75.03 \%$ in $\mathrm{ZnSo}_{4}$ but the smallest of the antimicrobial activity was $5.41 \%$ in $\mathrm{CuSo}_{4}$. Table 23, in addition, the strains $L$. pentosus $\mathrm{CH} 2$ which showed the largest growth inhibition $\%$ was $97.17 \%$ in $\mathrm{FeSo}_{4}$ against Bacillus subtilis NCIB3610 but the smallest was $15.5 \%$ in $\mathrm{ZnSo}_{4}$ wherever, the same strain was the largest growth inhibitor\% 93.11\% in $\mathrm{MgSo}_{4}$ against to E. coli but the smallest of the antimicrobial activity was $13.34 \%$ in $\mathrm{AgSo}_{4}$.

\subsubsection{Effect of Different Concentration of $\mathrm{NaCl}$ on Crude of Bacteriocins}

The effects of different concentration of $\mathrm{NaCl}$ on crude of bacteriocins were studied. In MRS broth, $2 \% \mathrm{NaCl}$ increased the activity of bacteriocins isolated from $\mathrm{Lac}$ tobacillus pentosus $\mathrm{CH} 2$ against to E.coli ATCC 25922 was $14 \mathrm{~mm}$, L. fermentum M1 was shown $15 \mathrm{~mm}$ against to Bacillus subtilis NCIB3610 (Table 24). Among them, bacteriocin from Lactobacillus pentosus $\mathrm{CH} 2$ against 
Study Bacteriocin Production and Optimization Using New Isolates of Lactobacillus spp.

Isolated from Some Dairy Products under Different Culture Conditions

Table 20. Effect of some mineral salt on crude bacteriocins from Lactobacillus fermentum M1.

\begin{tabular}{|c|c|c|c|c|c|c|}
\hline & \multicolumn{6}{|c|}{ Lactobacillus fermentus M1 } \\
\hline & \multicolumn{3}{|c|}{ Bacillus subtilis NCIB3610 } & \multicolumn{3}{|c|}{ E. coli ATCC 25922} \\
\hline & O.D & Growth \% & Growth inhibitor \% & O.D & Growth \% & Growth inhibitor $\%$ \\
\hline control & 0.813 & 100 & 0.00 & 1.350 & 100 & 0.00 \\
\hline $\mathrm{AgNO}_{3}$ & 0.844 & 103.8 & -3.8 & 2.221 & 164.5 & -64.5 \\
\hline $\mathrm{CuSO}_{4}$ & 0.493 & 60.63 & 39.36 & 2.221 & 164.5 & -64.5 \\
\hline $\mathrm{FeSO}_{4}$ & 0.104 & 12.79 & 87.20 & 1.185 & 87.76 & 12.23 \\
\hline $\mathrm{MgSO}_{4}$ & 0.301 & 37.03 & 62.98 & 0.177 & 13.11 & 86.89 \\
\hline $\mathrm{MnCl}_{2}$ & 0.216 & 26.57 & 73.43 & 2.301 & 170.44 & -70.44 \\
\hline $\mathrm{ZnSO}_{4}$ & 0.424 & 52.15 & 47.85 & 0.975 & 72.22 & 27.77 \\
\hline
\end{tabular}

Table 21. Effect of some mineral salt on crude bacteriocins from Lactobacillus acidophillus M2.

\begin{tabular}{|c|c|c|c|c|c|c|}
\hline & \multicolumn{6}{|c|}{ Lactobacillus acidophillus M2 } \\
\hline & \multicolumn{3}{|c|}{ Bacillus subtilis NCIB3610 } & \multicolumn{3}{|c|}{ E. coli ATCC 25922} \\
\hline & O.D & Growth \% & Growth inhibitor \% & O.D & Growth \% & Growth inhibitor \% \\
\hline control & 0.813 & 100 & 0.00 & 1.350 & 100 & 0.00 \\
\hline $\mathrm{AgNO}_{3}$ & 0.448 & 55.10 & 44.89 & 1.305 & 96.67 & 3.34 \\
\hline $\mathrm{CuSO}_{4}$ & 0.433 & 53.26 & 46.74 & 1.793 & 132.8 & -32.8 \\
\hline $\mathrm{FeSO}_{4}$ & 0.036 & 4.43 & 95.57 & 0.805 & 59.63 & 40.37 \\
\hline $\mathrm{MgSO}_{4}$ & 0.09 & 11.07 & 88.92 & 0.301 & 22.29 & 77.70 \\
\hline $\mathrm{MnCl}_{2}$ & 0.833 & 102.46 & -2.46 & 2.040 & 151.11 & -51.11 \\
\hline $\mathrm{ZnSO}_{4}$ & 0.297 & 36.53 & 63.47 & 2.20 & 162.96 & -62.96 \\
\hline
\end{tabular}

Table 22. Effect of some mineral salt on crude bacteriocins from Lactobacillus acidophillus CH1.

\begin{tabular}{ccccccc}
\hline & \multicolumn{5}{c}{ Lactobacillus acidophillus CH1 } \\
\cline { 2 - 7 } & O.D & Growth \% & Growth inhibitor \% & O.D & Growth \% & Growth inhibitor \% \\
\cline { 2 - 7 } & 0.813 & 100 & 0.00 & 1.350 & 100 & 0.00 \\
control & 0.665 & 81.79 & 18.20 & 2.096 & 155.25 & -55.25 \\
$\mathbf{A g N O}_{3}$ & 0.769 & 94.59 & $\mathbf{5 . 4 1}$ & 2.301 & 170.44 & -70.44 \\
$\mathbf{C u S O}_{4}$ & 0.265 & 32.59 & 67.40 & 0.028 & 2.07 & $\mathbf{9 7 . 9 2}$ \\
$\mathbf{F e S O}_{4}$ & 0.301 & 37.02 & 62.97 & 0.447 & 33.11 & $\mathbf{6 6 . 8 9}$ \\
$\mathbf{M g S O}_{4}$ & 0.700 & 86.10 & 13.89 & 2.484 & 184 & -84 \\
$\mathbf{M n C l}_{2}$ & 0.203 & 24.97 & $\mathbf{7 5 . 0 3}$ & 2.444 & 181.03 & -81.03 \\
$\mathbf{Z n S O}_{4}$ & & & &
\end{tabular}

Table 23. Effect of some mineral salt on crude bacteriocins from Lactobacillus pentosus CH2.

\begin{tabular}{lcccccc}
\hline & \multicolumn{7}{c}{ Lactobacillus pentosus CH2 } \\
\cline { 2 - 7 } & O.D & Growth \% & Growth inhibitor \% & O.D & Growth \% & Growth inhibitor \% \\
\cline { 2 - 7 } & 0.813 & 100 & 0.00 & 1.350 & 100 & 0.00 \\
control & 0.543 & 66.79 & 33.21 & 1.170 & 86.67 & $\mathbf{1 3 . 3 4}$ \\
$\mathbf{A g N O}_{3}$ & 0.685 & 84.26 & 15.74 & 2.461 & 182.3 & -82.3 \\
$\mathbf{C u S O}_{4}$ & 0.023 & 2.83 & $\mathbf{9 7 . 1 7}$ & 0.334 & 24.74 & 75.26 \\
$\mathbf{F e S O}_{4}$ & 0.201 & 24.73 & 75.27 & 0.093 & 6.89 & $\mathbf{9 3 . 1 1}$ \\
$\mathbf{M g S O}_{4}$ & 0.687 & 84.50 & $\mathbf{1 5 . 5}$ & 2.470 & 182.9 & -82.96 \\
$\mathbf{M n C l}_{\mathbf{2}}$ & 0.230 & 28.3 & 71.7 & 0.155 & 11.48 & 88.51 \\
$\mathbf{Z n S O}_{\mathbf{4}}$ & & & & & & \\
\hline
\end{tabular}


E. coli ATCC 25922 was shown $12 \mathrm{~mm}$, L. fermentum M1 was shown13 mm against to Bacillus subtilis NCIB3610 was showed activity in the presence of $4 \%$ $\mathrm{NaCl}$ concentration, but this activity at $6 \%$ and $8 \% \mathrm{NaCl}$. Two bacteriocins from L. pentosus $\mathrm{CH} 2$ and $L$. acidophilus M2 sawed 11 or $10 \mathrm{~mm}$. According to $10 \%$ $\mathrm{NaCl}$ concentration were shown no increase in their activity, but were inhibited by more than $1 \% \mathrm{NaCl}$ in MRS media. The supplementation with $\mathrm{NaCl}$, bacteriological peptone and beef extract have resulted in reduced activity. In contrast to the present observation, growth as well as bacteriocin production in the presence of bacteriological peptone or casamino acids and $\mathrm{NaCl}$ was reported to be higher by previous researchers $[43,44]$.

\subsubsection{Effect of Different Concentration of Amino Acids Component on Crude Bacteriocin Activity}

The effects of different concentrations of 21 esintial amino acid such as $2 \%, 4 \%, 6 \%, 8 \%$ and $10 \%$ on crude of bacteriocins were studied Table 25. In MRS broth, 2\% increased the activity of bacteriocins isolated from $\mathrm{Lac}$ tobacillus pentosus $\mathrm{CH} 2$ against to E. coli ATCC 25922 was $9 \mathrm{~mm}$ but the L. fermentum M1 was around $(8 \mathrm{~mm})$ activity, the $L$. acidophillus $\mathrm{M} 2$ and $L$. pentosus $\mathrm{CH} 2$ were no activity. The activity of $L$. fermentum M1 was showed $13 \mathrm{~mm}$ against to Bacillus subtilis NCIB3610. Among them, in $4 \%$, the largest activity of bacteriocin from Lactobacillus pentosus $\mathrm{CH} 2$ against $E$. coli ATCC 25922 was shown $10 \mathrm{~mm}$, but isolates were no activity against to Bacillus subtilis NCIB3610. Among them, 6\%, the largest activity of bacteriocin from L. acidophillus M2 against E. coli ATCC 25922 was shown $11 \mathrm{~mm}$, but isolates were no activity against to Bacillus subtilis NCIB3610. 8\%, the largest activity of bacteriocin from $L$. fermentum M1 against E. coli ATCC 25922 was shown $11 \mathrm{~mm}$, but isolates were no activity against to Bacillus subtilis NCIB3610. In 10\%, no activity for bacteriocin from Lactobacillus sp. against E. coli ATCC 25922 and Bacillus subtilis NCIB3610. So that, the activity of different bacteriocins were shown in $2 \%$ against $E$. coli ATCC 25922 and Bacillus subtilis NCIB3610.

\subsubsection{Effect of Different Vitamins Component on Crude Bacteriocin Activity}

The effects of different vitamins such as $\mathrm{B}_{12}$ and $\mathrm{B}$ complex on crude of bacteriocins were studied Table 26. In MRS broth, $\mathrm{B}_{12}$ increased the activity of bacteriocins isolated from Lactobacillus acidophillus $\mathrm{CH} 1$ against to E. coli ATCC 25922 was $10 \mathrm{~mm}$ but the three other isolates no activity were observed, wherever four isolates were shown 10 to $11 \mathrm{~mm}$ against to Bacillus subtilis NCIB3610. Among them, in B complex, bacteriocin from Lactobacillus acidophilus $\mathrm{CH} 1$ against $E$. coli ATCC 25922 was shown 13 to $14 \mathrm{~mm}$, the largest activity of bacteriocins for L. fermentum $\mathrm{M} 1$ and $L$. acidophilus CH1were shown $15 \mathrm{~mm}$ against to Bacillus subtilis NCIB3610 and the smallest was showed $5 \mathrm{~mm}$ in L. acidophilus $\mathrm{M} 2$ and L. pentosus $\mathrm{CH} 2$. This result was agree with Adenike et al. [45].

Table 24. Effect of different concentration of Nacl on crude bacteriocin.

\begin{tabular}{|c|c|c|c|c|c|c|c|c|}
\hline $\mathrm{NaCl}$ & & E. coli A & TCC 25922 & & & Bacillus subti & ilis NCIB3610 & \\
\hline Strains & $\begin{array}{c}L . \\
\text { fermentum M1 }\end{array}$ & $\begin{array}{c}L . \\
\text { acidophils M2 }\end{array}$ & $\begin{array}{c}L . \\
\text { Acidophils CH1 }\end{array}$ & $\begin{array}{c}L . \\
\text { pentosus } \mathrm{CH} 2\end{array}$ & $\begin{array}{c}L . \\
\text { Fermentum M1 }\end{array}$ & $\begin{array}{c}L . \\
\text { Acidophils M2 }\end{array}$ & $\begin{array}{c}L . \\
\text { Acidophils CH1 }\end{array}$ & $\begin{array}{c}L . \\
\text { pentosus } \mathrm{CH2}\end{array}$ \\
\hline Control & 2 & 3 & 9 & 5 & 3 & 4 & 16 & 2 \\
\hline $2 \%$ & 10 & 11 & 11 & 14 & 15 & 14 & 10 & 10 \\
\hline $4 \%$ & 9 & 6 & 10 & 12 & 13 & 11 & 9 & 11 \\
\hline $6 \%$ & 0.0 & 0.0 & 9 & 11 & 5 & 10 & 9 & 10 \\
\hline $8 \%$ & 0.0 & 0.0 & 0.0 & 0.0 & 10 & 9 & 7 & 5 \\
\hline $10 \%$ & 0.0 & 0.0 & 0.0 & 0.0 & 0.0 & 0.0 & 0.0 & 0.0 \\
\hline
\end{tabular}

Table 25. Effect of adding 21 amino acid on crude bacteriocin.

\begin{tabular}{|c|c|c|c|c|c|c|c|c|}
\hline \multirow{2}{*}{$\begin{array}{l}21 \text { amino } \\
\text { acid }\end{array}$} & \multicolumn{4}{|c|}{ E. coli } & \multicolumn{4}{|c|}{ B. subtilis } \\
\hline & $\begin{array}{c}\text { L. fermentum } \\
10 \\
\end{array}$ & $\begin{array}{c}\text { L. acidophilus } \\
110\end{array}$ & $\begin{array}{c}\text { L. acidophilus } \\
111\end{array}$ & $\begin{array}{c}\text { L. pentosus } \\
160\end{array}$ & $\begin{array}{c}\text { L. fermentum } \\
10\end{array}$ & $\begin{array}{c}\text { L. acidophilus } \\
110\end{array}$ & $\begin{array}{c}\text { L. acidophilus } \\
111\end{array}$ & $\begin{array}{c}\text { L. pentosus } \\
160\end{array}$ \\
\hline $2 \%$ & 8 & 0.0 & 0.0 & 9 & 13 & 12 & 11 & 0.9 \\
\hline $4 \%$ & 7 & 5 & 7 & 10 & 0.0 & 0.0 & 0.0 & 0.0 \\
\hline $6 \%$ & 0.0 & 11 & 9 & 0.0 & 7 & 5 & 6 & 0.0 \\
\hline $8 \%$ & 11 & 10 & 7 & 0.0 & 0.0 & 0.0 & 0.0 & 0.0 \\
\hline $10 \%$ & 9 & 0.0 & 0.0 & 10 & 9 & 7 & 5 & 0.0 \\
\hline
\end{tabular}


Table 26. Effect of adding some vitamins on crude bacteriocin.

\begin{tabular}{ccccc}
\hline Sitamins & \multicolumn{2}{c}{$\mathbf{B}_{12}$} & \multicolumn{2}{c}{ B comple } \\
\cline { 2 - 5 } Strains & E. coli & B. subtilis & E. coli & B. subtilis \\
\hline $\begin{array}{c}\text { L. fermentum } \\
\mathbf{1 0}\end{array}$ & 0.0 & 11 & 14 & 11 \\
$\begin{array}{c}\text { L. acidophilus } \\
\quad \mathbf{1 1 0}\end{array}$ & 0.0 & 10 & 13 & 5 \\
$\begin{array}{c}\text { L. acidophilus } \\
\mathbf{1 1 1}\end{array}$ & 10 & 11 & 14 & 11 \\
$\begin{array}{c}\text { L. pentosus } \\
\mathbf{1 6 0}\end{array}$ & 0.0 & 11 & 10 & 5 \\
\hline
\end{tabular}

\section{Conclusions}

Bacteriocin production was strongly dependent on $\mathrm{pH}$, nutrients source and temperature various physicochemical factors seemed to affect bacteriocin production as well as its activity.

The bacteriocin suspension of Lactobacillus spp. grown in MRS broth had the best inhibitory effect against wide spectrum of bacteria. The present study demonstrated the production of the bacteriocin by four lactobacilli isolates under different culture conditions. Its antimicrobial potency, $\mathrm{pH}$ stability, activity retention in low and high temperatures suggested its wide applicability in acidic $\mathrm{pH}$ conditions and in pre-processed food products. Further research though, should be performed to develop extraction techniques for lactic acid and bacteriocins and test further their production on the nutrient media.

\section{REFERENCES}

[1] F. Leroy and L. De Vuyst, "Lactic Acid Bacteria as Functional Starter Cultures for the Food Fermentation Industry," Trends in Food Science \& Technology, Vol. 15, No. 2, 2004, pp. 67-78. doi:10.1016/j.tifs.2003.09.004

[2] M. A. Riley and J. E. Wertz, "Bacteriocins: Evolution, Ecology, and Application," Annual Review of Microbiology, Vol. 56, No. 3, 2002, pp. 117-137. doi:10.1146/annurev.micro.56.012302.161024

[3] R. W. Jack, J. R. Tagg and B. Ray. "Bacteriocins of GramPositive Bacteria," Microbiology Reviews, Vol. 59, No. 2, 1995, pp. 171-200.

[4] M. Papagianni, "Ribosomally Synthesized Peptides and Antimicrobial Properties: Biosynthesis, Structure, Function, and Applications," Biotechnology Advances, Vol. 21, No. 6, 2003, pp. 465-499. doi:10.1016/S0734-9750(03)00077-6

[5] J. R. Tagg, A. S. Dajani and L. W. Wannamaker, "Bacteriocins of Gram-Positive Bacteria," Bacteriological Reviews, Vol. 40, No. 3, 1976, pp. 722-756.

[6] P. D. Cotter, C. Hill and R. P. Ross, "Bacteriocins: Developing Innate Immunity for Food," Nature Reviews: Microbiology, Vol. 3, No. 10, 2005, pp. 777-788. doi:10.1038/nrmicro1273

[7] J. J. Mortvedt, F. R. Cox, L. M. Shuman and R. M. Welch,
"Micronutrients in Agriculture," 2nd Edition, Soil Science Society of America, Madison, 1991.

[8] A. S. Karaoğlu, A. Faruk, S. S. Kiliç and A. O. Kiliç, "Antimicrobial Activity and Characteristics of Bacteriocins Produced by Vaginal Lactobacilli," Turkish Journal of Medical Sciences, Vol. 33, No. 1, 2003, pp. 7-13.

[9] S. Ennahar, K. Sonomoto and A. Ishizaki, "Class IIa Bacteriocins from Lactic Acid Bacteria: Antibacterial Activity and Food Preservation," Journal of Bioscience and Bioengineering, Vol. 87, No. 6, 1999, pp. 705-716. doi:10.1016/S1389-1723(99)80142-X

[10] J. C. De Man, M. Rogosa and M. E. Sharpe, “A Medium for the Cultivation of Lactobacilli," Journal of Applied Microbiology, Vol. 23, No. 1, 1960, pp. 130-135. doi:10.1111/j.1365-2672.1960.tb00188.x

[11] Bergey's Manual of Systematic Bacteriology, "Online Version of Bergey's Manual," 2004. www.reference.com/motif/science/Online-Version-of-Ber ge

[12] O. Kandler and N. Weiss, "Regular, Nonsporing GramPositive Rods," In: P. H. A. Sneath, N. S. Mair, M. E. Sharpe and J. G. Holt, Eds., Bergey's Manual of Systematic Bacteriology, Williams and Williams, Baltimore, 1986, pp. 1208-1234.

[13] J. G. Holt, N. R. Krig, J. T. Staley and S. T. Williams, "Gram Positive Cocci. Bergey'z Manual of Determinative Bacteriolog," 9th Edition, Springer, New York, Baltimore, 1994, pp. 528-540.

[14] G. M. Garrity, J. A. Bell and T. G. Lilbum, "Taxonomic Outline of The Prokaryotes Bergey's Manual of Systematic Bacteriology," 2nd Edition, Springer, New York, Berlin, Heidelberg, 2004.

[15] British Standards Institution (BSI), "Methods on Microbial Examination for Dairy Purposes," British Standards Institution, British Standards House, London, 1968.

[16] J. N. Eloff, “A Sensitive and Quick Microplate Method to Determine the Minimal Inhibitory Concentration of Plant Extract for Bacteria," Planta Medica, Vol. 64, No. 8, 1998, pp. 711-713. doi:10.1055/s-2006-957563

[17] M. Cole, "Formation of 6-Aminopenicillanic Acid, Penicillins and Penicillin Acylase by Various Fungi," Applied Microbiology, Vol. 14, No. 1, 1966, pp. 98-104.

[18] M. Cole, "Hydrolysis of Penicillins and Related Compounds by the Cell-Bound Penicillin Acylase of Escherichia coli," The Biochemical Journal, Vol. 115, No. 4, 1966, pp. 733-739.

[19] V. Bihari and K. Buchholz, "Kinetics \& Effectiveness of Soluble \& Immobilized Penicillin Acylase (E. coli) in Different Forms," Indian Journal of Experimental Biology, Vol. 21, No. 1, 1983, pp. 27-30.

[20] U. Schillinger and F. K. Lücke, "Antibacterial Activity of Lactobacillus sake Isolated from Meat," Applied and Environmental Microbiology, Vol. 55, No. 8, 1989, pp. 1091-1096.

[21] H. Daba, S. Pandian, J. F. Gosselin, R. E. Simard, J. Huang and C. Lacroix, "Detection and Activity of Bacteriocin Produced by Leuconostoc mesenteriodes," Applied 
and Environmental Microbiology, Vol. 57, No. 12, 1991, pp. 3450-3455.

[22] S. T. Ogunbanwo, A. I. Sanni and A. A. Onilude, "Characterization of Bacteriocin Produced by Lactobacillus plantarum F1 and Lactobacillus brevis OG1," African Journal of Biotechnology, Vol. 2, No. 8, 2003, pp. 219227.

[23] P. M. Muriana and T. R. Klaenhammer, "Purification and Partial Characterization of Lactacin F, a Bacteriocin Produced by Lactobacillus acidophilus 11088," Applied and Environmental Microbiology, Vol. 57, No. 1, 1991, pp. 114-121.

[24] K. Adinarayana and P. Ellaiah, "Response Surface Optimization of the Critical Medium Components for the Production of the Alkaline Protease by a Newly Isolated Bacillus sp.," Journal Pharmacy \& Pharmaceutical Sciences, Vol. 5, No. 3, 2003, pp. 272-278.

[25] W. F. Harigon and M. E. McCane, "Laboratory Methods in Foods and Dairy Microbiology," In: W. F. Harigon and M. E. McCane, Eds., Laboratory Methods in Foods and Dairy Microbiology, Academic Press, New York, 1976, pp. 12-15.

[26] A. Galvez, R. L. Lopez, H. Abriouel, E. Valdivia and N. B. Omar, "Application of Bacteriocins in the Control of Food Borne Pathogenic and Spoilage Bacteria," Critical Reviews in Biotechnology, Vol. 28, No. 2, 2008, pp. 125152. doi: $10.1080 / 07388550802107202$

[27] S. H. Ko and C. Ahn, "Bacteriocin Production by Lactococcus lactis KCA2386 Isolated from White Kimchi," Food Science and Biotechnology, Vol. 9, No. 4, 2000, pp. 263-269.

[28] A. R. Sarika, "Optimization Analysis of Free and Immobilized Bacteriocin Elaborated by Lactobacillus plantarum MTCC B 1746 and Lactococcus lactis MTCC B 440," M.Sc. Dissertation, Manonmaniam Sundaranar University, Thirunelveli, 2003, p. 54.

[29] H. S. Chin, J. S. Shim, J. M. Kim, R. Yang and S. S. Yoon, "Detection and Antibacterial Activity of a Bacteriocin Produced by Lactobacillus plantarum," Food Science and Biotechnology, Vol. 10, No. 2, 2001, pp. 335341.

[30] M. S. Juarez Tomas, E. Bru, B. Wiese, A. Pesce de Ruiz Holgado and M. E. Nader-Macias, "Influence of $\mathrm{pH}$, Temperature and Culture Media on the Growth and Bacteriocin Production by Vaginal Lactobacillus salivarius CRL 1328," Journal Applied Microbiology, Vol. 93, No. 4, 2002, pp. 714-724. doi:10.1046/j.1365-2672.2002.01753.x

[31] B. E. Terzaghi and W. E. Sandine, "Improved Medium for Lactic Streptococci and Their Bacteriophages," $A p$ plied Microbiology, Vol. 29, No. 6, 1975, pp. 807-813.

[32] P. Raibaud, J. V. Galpin, R. Ducluzeau, G. Mocquot and G. Oliver, "The 'Lactobacillus' Genus in the Digestive Tract of Rats. II. Characteristics of Heterofermentative Strains Isolated from 'Holo-' and 'Gnotoxenic' Rats," Annales de Microbiologie, Vol. 124, No. 2, 1973, pp. 223-235.

[33] S. R. Biswas, P. Ray, M. C. Johnson and B. Ray, "Influence of Growth Conditions on the Production of a Bacte- riocin, Pediocin AcH by Pediococcus acidilactici $\mathrm{H}, "$ Applied and Environmental Microbiology, Vol. 57, No. 4, 1991, pp. 1265-1267.

[34] V. Karthikeyan and S. W. Santosh, "Isolation and Partial Characterization of Bacteriocin Produced from Lactobacillus plantarum," African Journal of Microbiology Research, Vol. 3, No. 5, 2009, pp. 233-239.

[35] A. A. O. Ogunshe, M. O. Omotoso and A. D. V. Ayansina, "Microbial Studies and Biochemical Characteristics of Controlled Fermented Afiyo-A Nigerian Fermented Food Condiment from Prosopis africana (Guill and Perr.) Taub," Pakistan Journal of Nutrition, Vol. 6, No. 6, 2007, pp. 620-627. doi:10.3923/pjn.2007.620.627

[36] Ö. Şimşek, A. H. Çon and Ş. Tulumoĝlu, "Isolating Lactic Starter Cultures with Antimicrobial Activity for Sourdough Processes," Food Control, Vol. 17, No. 4, 2009, 263-270. doi:10.1016/j.foodcont.2004.10.011

[37] H. Fukushima, J. Kelstrup, S. Fukushima, T. Umemoto and H. Sagawa, "Isolation, Partial Purification and Preliminary Characterization of a Bacteriocin from Streptococcus mutants Rm-10," Antonie van Leeuwenhoek, Vol 49, No. 1, 1983, pp. 41-50. doi:10.1007/BF00457878

[38] M. C. Audisto, G. Oliver and M. C. Apella, "Effect of Different Complex Carbon Sources on Growth and Bacteriocin Synthesis of Enterococcus faecium," Int. J. Food Microbiol., 2001, 63, 235-241. doi:10.1016/S0168-1605(00)00429-3

[39] R. Geisen, B. Becker and W. H. Holzapfel, "Modelling the Bacteriocin Production of Leuconostoc carnosum," FEMS Microbiology Reviews, 1993, Vol. 12-S, pp. $337-$ 340.

[40] G. Vignolo, S. Fadda, M. N. DeKairuz, A. A. P. De Ruiz Holgdo and G. Olivier, "Control of Listeria monocytogenes in Ground Beef by B. E. Terzaghi and W. E. Sandine," Applied Microbiology, Vol. 29, No. 60, 1975, p. 807.

[41] L. De Vugst and E. J. Vandamme, "Bacteriocins of Lactic Acid Bacteria, Microbiology, Genetic Application,” Blackie Academy and Professional, London, 1994.

[42] S. Saharan, N. Dilbaghi and S. Sharma, "Optimization of Medium Conditions for the Production of Bacteriocin-SN21 by Lactobacillus acidophilus," Indian Journal of Microbiology, Vol. 38, No. 4, 1998, pp. 225-227.

[43] S. D. Todorov and L. M. T. Dicks, "Lactobacillus plantarum Isolated from Molasses Produces Bacteriocins Active against Gram-Negative Bacteria," Enzyme and Microbial Technology, Vol. 36, No. 2-3, 2005, pp. 318-326. doi:10.1016/j.enzmictec.2004.09.009

[44] N. E. Pingitore Jr., J. W. Clague, M. A. Amaya, B. Maciejewska and J. J. Reynoso, "Urban Airborne Lead: XRay Absorption Spectroscopy Establishes Soil as Dominant Source," PLoS ONE, Vol. 4, No. 4, 2009, Article ID; e5019. doi:10.1371/journal.pone.0005019

[45] A. O. A. Ogunshe1, M. Z. Johnny and A. O. Arinze, "Effects of Food Spices on Gram-Negative Food Indicator Bacteria from Some Nigerian Ethnic Fermented Plant Food Condiments," African Journal of Plant Science, Vol. 6, No. 1, 2012, pp. 8-14. 